\title{
Evaluation of Ultrasonography as a Diagnostic Tool in Maxillofacial Space Infections
}

\author{
Praveen Kumar Pandey ${ }^{1}$, Meenaxi Umarani², Sharadindu Kotrashetti², Shridhar Baliga ${ }^{2}$ \\ ${ }^{1}$ Department of Oral and Maxillofacial Surgery, Saraswati Dental College and Hospital, Lucknow, India. \\ ${ }^{2}$ Department of Oral and Maxillofacial Surgery, K.L.E.V.K Institute of Dental Sciences, Belgaum, India.
}

\author{
Corresponding Author: \\ Meenaxi Umarani \\ Department of Oral and Maxillofacial Surgery \\ K.L.E .V.K Institute of Dental Sciences \\ Nehru Nagar, Belgaum-590010 \\ India \\ Phone: 09342997096 \\ Fax: 0831-2470640 \\ E-mail: meenaxi@rediffmail.com
}

\begin{abstract}
Objectives: The purpose of the study was to establish the role of ultrasonography in determining the involvement of specific fascial spaces in maxillofacial region and the stage of infection, in indicating the appropriate time for surgical intervention and to compare clinical and ultrasonographic findings.

Material and Methods: Twenty five patients with fascial space infection in maxillofacial region were subjected to ultrasonographic examination following a detailed clinical and radiological examination. Ultrasonography guided needle aspiration was performed. Based on the findings, patients diagnosed with abscess were subjected to incision and drainage and those with cellulitis were subjected to medical line of treatment.

Results: More than one fascial space was involved in all patients. On clinical examination 64 spaces were involved, of them 34 spaces had abscess formation and 30 spaces were in the stage of cellulitis. On ultrasonography examination, 28 spaces were reported to have abscess formation and 36 spaces were diagnosed to be in the stage of cellulitis. On comparative analysis of both clinical and ultrasonographic findings, ultrasonography was found to be sensitive in $65 \%$ of the cases and having specificity of $80 \%$. It was registered statistically significant $(\mathrm{P}<0.001)$ agreement between these two methods of assessment (kappa index $=0.814$ ).

Conclusions: Ultrasonography is a quick, widely available, relatively inexpensive, and painless procedure and can be repeated as often as necessary without risk to the patient. Thus ultrasonography is a valuable diagnostic aid to the oral and maxillofacial surgeon for early and accurate diagnosis of fascial space infection, their appropriate treatment and to limit their further spread.
\end{abstract}

Keywords: ultrasonography; maxillofacial surgery; abscess; cellulitis; differential diagnosis.

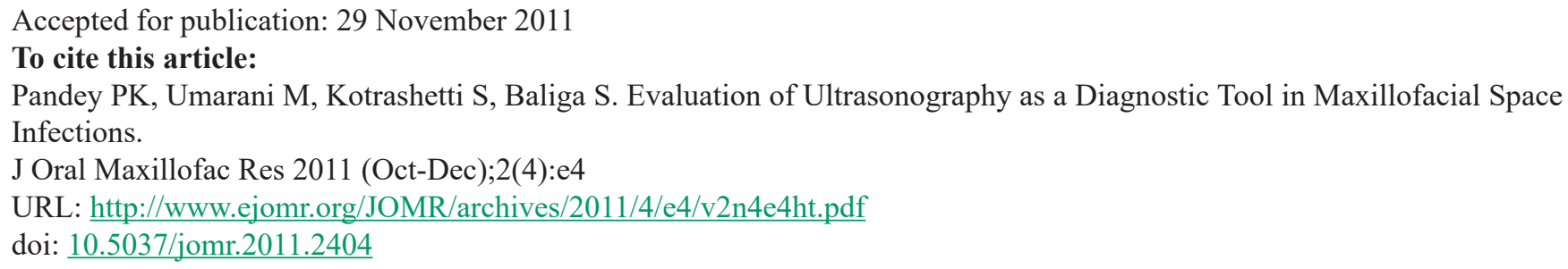




\section{INTRODUCTION}

Infections are frequently encountered in day to day practice of oral and maxillofacial surgery which has the potential to spread through the fascial planes to the head and neck region to compromise the vital structures. These infections often respond to surgical and antimicrobial management if diagnosed and treated appropriately.

To know whether the inflammatory process is in the stage of cellulitis that can be treated by antibiotics alone or abscess formation which requires primary evacuation of pus and administration of antibiotics is inevitable in the case of acute odontogenic infections. Clinically it is often difficult to diagnose the stage of infection and to define its exact location [1]].

The anatomical location of abscess in patients with odontogenic infection is commonly determined by physical examination, but abscess of deep subcutaneous layer can be difficult to diagnose [2-4]. The relatively blind surgical incision and drainage of an abscess based on diagnosis by physical examination alone usually results in excessive harm, unnecessary extensive incisions, excess time, and failure to locate and evacuate the abscess cavity $[\underline{5}, \underline{6}]$. There are various diagnostic tools available which have minimized this therapeutic dilemma for surgeons to precisely diagnose and delineate the extent, and location of the lesion [7]. Plain radiographs do not provide good definition of soft tissues [ [ ] . Computer tomography (CT) scans and magnetic resonance imaging (MRI) are effective in diagnosing inflammatory conditions but are expensive and, suffer from some disadvantages [1].

In light of these factors, the aim of the study was to evaluate the use of ultrasonography as a diagnostic tool for fascial spaces infections in maxillofacial region. short duration, diffuse margins, lack of fluctuancy and inflamed overlying skin were considered clinically as cellulitis (Figure 1). Well localized swellings with history of longer duration and presence of fluctuancy were diagnosed as abscess.

After obtaining the informed consent complete blood investigations were done and patients were subjected to ultrasonographic (USG) examination and reports obtained (Figures 2 and 3). A 7.5 MHz linear or a convex transducer (L\&T Medical Selectra LX, Biometric cables, Chennai, India) was applied over the skin with ultrasound equipment (ACUSON X300, Siemens AG, Erlangen, Germany) covering the suspected area in transverse and axial sections to determine the presence or absence of fluid collection and its location.

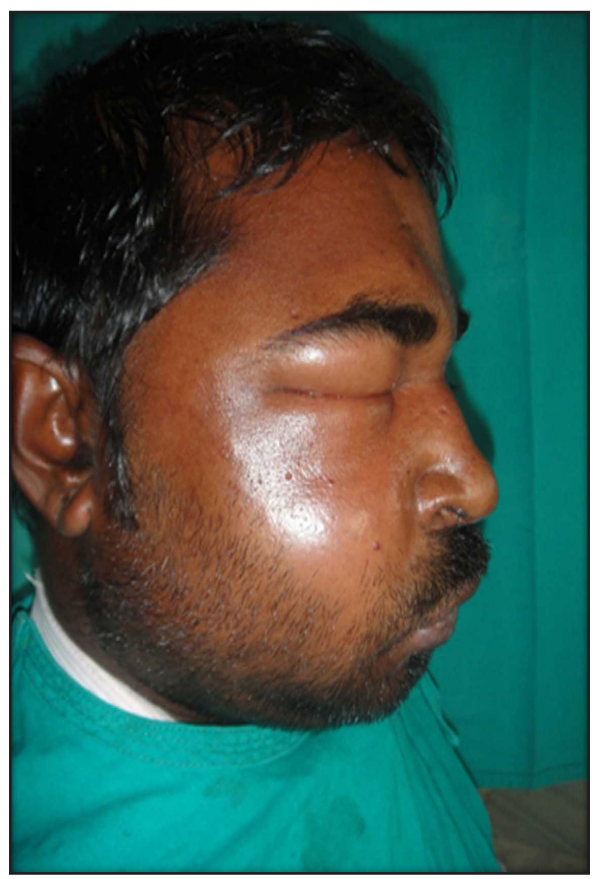

Figure 1. Photograph showing patient with buccal space abscess, canine and submandibular space cellulitis.

\section{MATERIAL AND METHODS}

This clinical study was approved by the institutional review board and the ethical commission and written informed consent was obtained from patients. Twenty five patients reporting to KLE hospital and medical research centre, Belgaum, India during the period 2007 to 2008 were included in the study. Patients presenting with signs and symptoms of maxillofacial space infections, 12 male and 13 female with an average age of 40 (SD 7.4) years were studied. A detailed history and clinical and radiographic examination of the swelling was carried out by a single examiner (P.K.P.) in a systematic manner. Swellings with history of

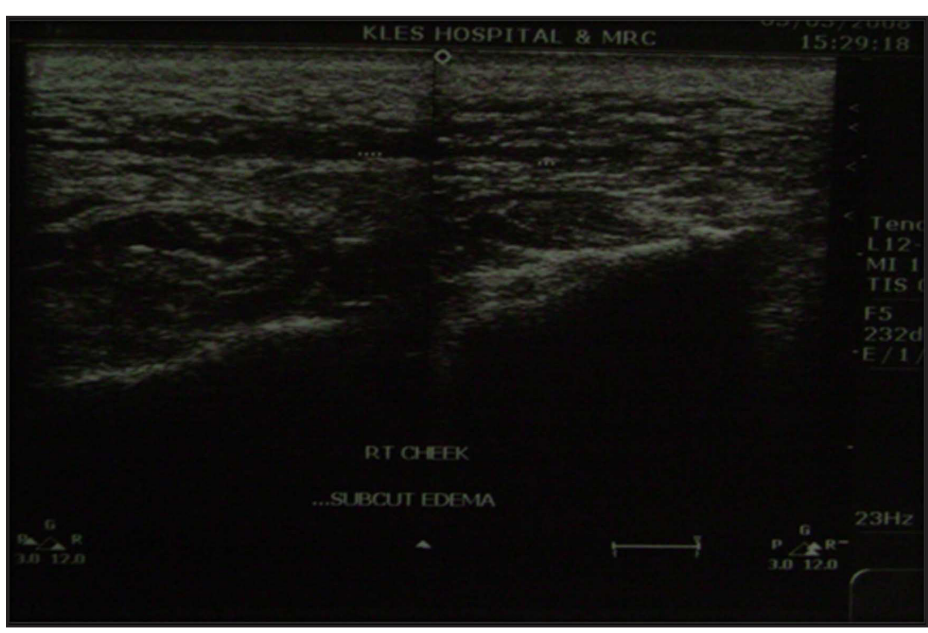

Figure 2. Ultrasonographic image showing cellulitis of buccal and canine spaces. 


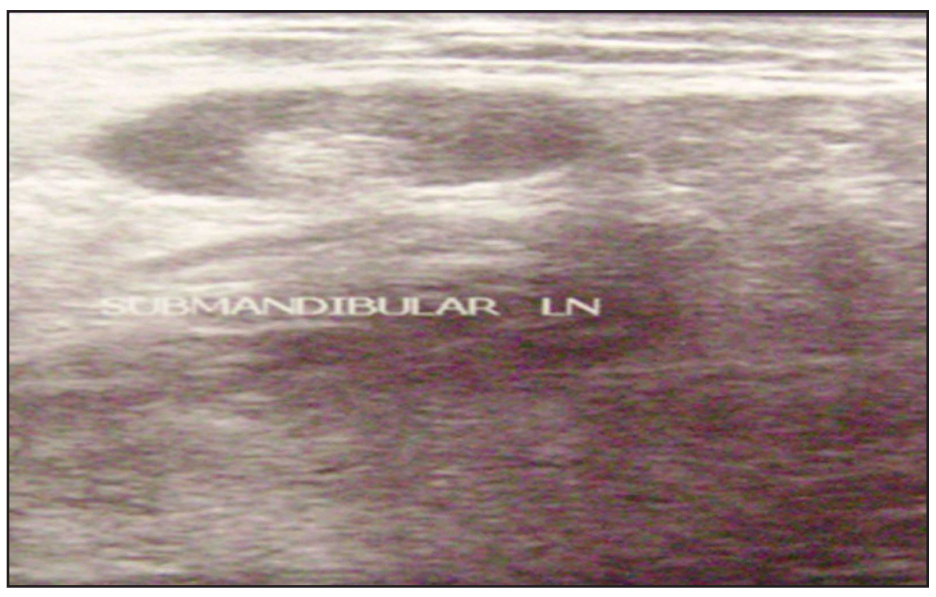

Figure 3. Ultrasonographic image showing cellulitis of buccal and canine spaces.

USG guided needle aspiration was then carried out to conform the fluid collection and pus sent for culture and sensitivity. After diagnosis statement surgical and medicament treatment was applied.

\section{Statistical analysis}

Clinical findings were correlated with USG findings using kappa analysis. The difference between two groups was considered as statistically significant, when $\mathrm{P}<0.05$.

\section{RESULTS}

Of the 25 patients, 4 presented with buccal swelling, 6 with submandibular swelling, 10 with buccal and submandibular swelling, 3 had buccal and infraorbital swelling and 2 presented with buccal, submandibular and infraorbital swelling (Table 1). All these 25 patients were evaluated clinically and radiographically. There was involvement of more than one space in most of the patients. In total 64 spaces were diagnosed clinically in 25 patients, out of which 34 spaces had abscess formation and the rest 30 spaces were in the stage of cellulitis.

Further, all these patients were subjected to USG examination. Twenty eight spaces were reported to have fluid collection, suggestive of abscess formation and rest 36 spaces were diagnosed to be in the stage of cellulitis (Table 2). Considering the number of spaces involved, clinical findings were correlated with USG findings (Figure 4) and there was statistically significant agreement between these two methods of assessment (kappa index $=0.814$, $\mathrm{P}<0.001$ ). It was found that USG is sensitive in $65 \%$ of the cases, having specificity of $80 \%$. Patients diagnosed with abscess formation were primarily subjected to surgical incision and drainage under antibiotic coverage. Patients diagnosed as having cellulitis were admitted to the wards and parenteral antibiotics were administered along with supportive therapy.

\section{DISCUSSION}

Infections treated by oral and maxillofacial surgeons are often odontogenic in origin. Although spatially confined, purulent material may spread deeply into contiguous fascial spaces such as the submandibular, sublingual and pterygomandibular spaces. Severe complications such as mediastinitis, intra-cranial abscess

Table 1. Fluid collection identified by ultrasonography (USG)

\begin{tabular}{|c|c|c|c|}
\hline Clinical Features & Number of Patients & $\begin{array}{l}\text { Fluid collection spaces identified by } \\
\text { USG }\end{array}$ & Number of spaces \\
\hline \multirow{2}{*}{ Buccal swelling } & \multirow{2}{*}{4} & Buccal space & 3 \\
\hline & & Submasseteric space & - \\
\hline \multirow{2}{*}{ Submandibular swelling } & \multirow{2}{*}{6} & Submandibular space & 3 \\
\hline & & Submental space & 4 \\
\hline \multirow{4}{*}{ Buccal and submandibular swelling } & \multirow{4}{*}{10} & Buccal space & 3 \\
\hline & & Sumasseteric space & 5 \\
\hline & & Submandibular space & 7 \\
\hline & & Submental space & - \\
\hline \multirow{2}{*}{ Buccal and infraorbital swelling } & \multirow{2}{*}{3} & Buccal space & - \\
\hline & & Canine space & 1 \\
\hline \multirow[t]{2}{*}{$\begin{array}{l}\text { Buccal, infraorbital and submandibular } \\
\text { swelling }\end{array}$} & 2 & Buccal, canine and submandibular space & 2 \\
\hline & & $\begin{array}{l}\text { Total number of spaces with fluid } \\
\text { collection }\end{array}$ & 28 \\
\hline
\end{tabular}




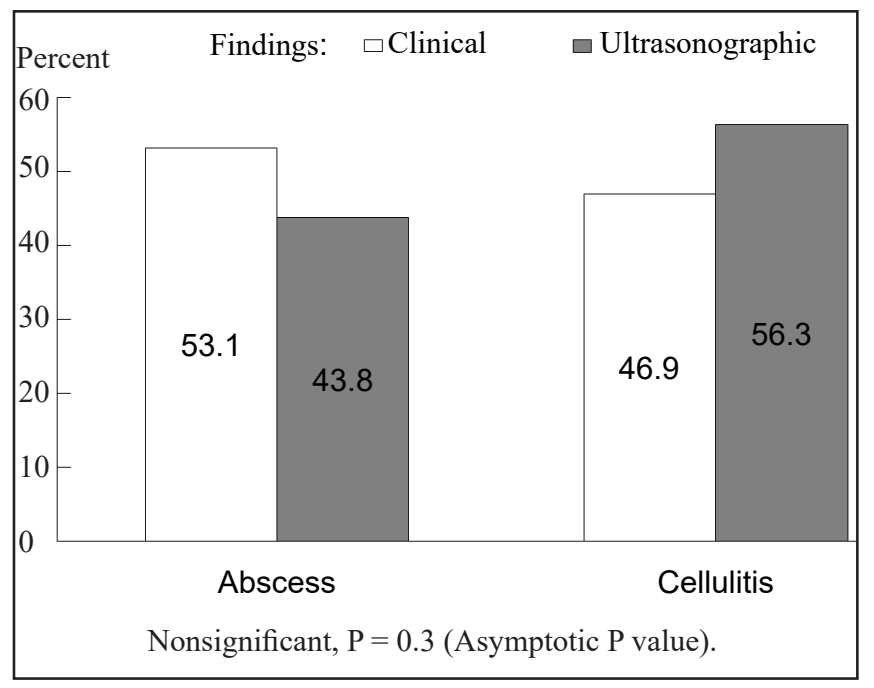

Figure 4. Graph showing clinical and ultrasonographic findings correlation.

and parapharyngeal spread with airway obstruction can result if the infection is not recognized and treated promptly. In case of rapidly spreading infections, securing the airway and broad spectrum intravenous antibiotic therapy are recognized as 'cornerstones' of treatment [9]. A finding of fluctuance is often difficult on clinical examination, especially in spaces such as the submasseteric, where purulent material is deep within the soft tissues and muscle [1]. Despite of various diagnostic modalities which are available as an adjuvant to clinical examination, USG seems to play an important role in reducing the therapeutic dilemma to a great extent.

Radiographs and other imaging studies can be used to diagnose the spreading infections in the head and neck area but plain radiographs do not often provide a good definition of soft tissues. CT and MRI are effective in diagnosing inflammatory conditions and choice between these two techniques usually depends on the area involved. However, both techniques are expensive. CT exposes the patient to large doses of radiation especially if repeated follow-up examinations are to be performed. Artefact produced by bone and metal degrade images around the face. Another significant disadvantage is the poor contrast between the various soft tissues. The major disadvantage of MRI is the prolonged time for image acquisition, and also the image may suffer from the effects of the patient motion. The high static magnetic field also poses a danger to those individuals with cardiac pacemakers, neurostimulator units and intraocular therapeutic devices $[10,11]$.

For many years, USG has played a major role as a diagnostic tool in various medical conditions. In maxillofacial surgery, it is relatively a new diagnostic aid. The USG examination has been used to evaluate various masses in the neck and cysts, tumours, swellings, and similar processes in soft tissues of the cranio-facial
Table 2. Correlation of ultrasonographic and clinical findings

\begin{tabular}{lccc}
\hline \multirow{2}{*}{ Ultrasonographic findings } & \multicolumn{2}{c}{ Clinical findings } & \multirow{2}{*}{ Total } \\
\cline { 2 - 3 } & Abscess & Cellulitis & \\
\hline Abscess & 22 & 6 & 28 \\
\hline Cellulitis & 12 & 24 & 36 \\
\hline Total & 34 & 30 & 64 \\
\hline
\end{tabular}

region [ $[\underline{]}$.

It offers potential advantage because it can be performed noninvasively, repeatedly, and easily, even at the bed side [12]. With the aid of high-resolution transducer, ultrasound shows the internal muscle structures more clearly than does CT [13].

USG is an effective diagnostic tool to confirm abscess formation in the superficial fascial spaces and is highly predictable in detecting the stage of infection (Figures 1, 2 and 3). It has the ability to pinpoint the relation of the abscess to the overlying skin, accurately measure the dimensions of the abscess cavity, and its precise depth below the skin surface [ $\underline{6}]$.

The principle of USG is based on the fact that, there are large differences in the impedance for ultrasound waves between soft tissue and air, and between soft tissue and bone. Bone and air are absolute barriers to an ultrasound beam, this means that no image within or behind bony or air containing structure can be produced by ultrasound. Therefore some regions of maxillofacial field cannot be evaluated by ultrasound, such as the retropharyngeal region and paranasal sinuses. No echoes are returned by fluids and thus USG is very sensitive in detecting fluid collections as in case of maxillofacial infections [14]. Though USG cannot differentiate an abscess from surrounding blood vessels, but combination of colour doppler ultrasonography with grey scale has solved this problem. The target of colour doppler imaging is the moving blood cells within the blood vessel. The vessels of the inflammatory tissue which has a higher blood volume due to increased permeability of the vessel wall are depicted as a colour flow signal. Blood flowing towards the USG transducer is displayed as red and that moving away from transducer as blue. In contrast the retained pus which does not contain flowing blood cells is delineated as no colour flow signal. This property of doppler ultrasonography allows it to differentiate blood vessels from static regions of images [15].

\section{CONCLUSIONS}

As a diagnostic tool ultrasonography imaging stands as a non-invasive, cost effective, readily available and repeatable technique. It is relatively easy to use 
and does not involve ionizing radiation. The machine is portable and can be used in real time during surgery. Except with few short-comings USG surpasses all the other diagnostic modalities especially in cases of maxillofacial space infections. In our study ultrasonography has been useful in detecting abscess formation in maxillofacial spaces and highly predictable

\section{ACKNOWLEDGMENTS AND DISCLOSURE STATEMENTS}

The authors declare that they have no conflict of interests.

\section{REFERENCES}

1. Peleg M, Heyman Z, Ardekian L, Taicher S. The use of ultrasonography as a diagnostic tool for superficial fascial space infections. J Oral Maxillofac Surg. 1998 Oct;56(10):1129-31; discussion 1132. [Medline: 9766536] [doi: 10.1016/S0278-2391(98)90751-0]

2. Baatenburg de Jong RJ, Rongen RJ, Laméris JS, Knegt P, Verwoerd CD. Ultrasound-guided percutaneous drainage of deep neck abscesses. Clin Otolaryngol Allied Sci. 1990 Apr;15(2):159-66. [Medline: 2190716]

3. Kreutzer EW, Jafek BW, Johnson ML, Zunkel DE. Ultrasonography in the preoperative evaluation of neck abscesses. Head Neck Surg. 1982 Mar-Apr;4(4):290-5. [Medline: 7085319] [doi: 10.1002/hed.2890040405]

4. Sakaguchi M, Sato S, Ishiyama T, Katsuno S, Taguchi K. Characterization and management of deep neck infections. Int J Oral Maxillofac Surg. 1997 Apr;26(2):131-4. [Medline: 9151171] [doi: 10.1016/S0901-5027(05)80835-5]

5. Yusa H, Yoshida H, Ueno E, Onizawa K, Yanagawa T. Ultrasound-guided surgical drainage of face and neck abscesses. Int J Oral Maxillofac Surg. 2002 Jun;31(3):327-9. [Medline: 12190142] [doi: 10.1054/ijom.2002.0233]

6. Baurmash HD. Ultrasonography in the diagnosis and treatment of facial abscesses. J Oral Maxillofac Surg. 1999 May;57(5):635-6. [Medline: 10319844] [doi: 10.1016/S0278-2391(99)90112-X]

7. Hell B. B-scan sonography in maxillo-facial surgery. J Cranio Maxillo Facial Surgery 1989 Jan;(17):39-45. [doi: 10.1016/S1010-5182(89)80126-X]

8. Siegert R. Ultrasonography of inflammatory soft tissue swellings of the head and neck. J Oral Maxillofac Surg. 1987 Oct;45(10):842-6. [Medline: 3309224] [doi: 10.1016/0278-2391(87)90233-3]

9. Ridder GJ, Technau-Ihling K, Sander A, Boedeker CC. Spectrum and management of deep neck space infections: an 8-year experience of 234 cases. Otolaryngol Head Neck Surg. 2005 Nov;133(5):709-14. [Medline: 16274797] [doi: 10.1016/j.otohns.2005.07.001]

10. Ariji E, Ariji Y, Yoshiura K, Kimura S, Horinouchi Y, Kanda S. Ultrasonographic evaluation of inflammatory changes in the masseter muscle. Oral Surg Oral Med Oral Pathol. 1994 Dec;78(6):797-801. [Medline: 7898913] [doi: 10.1016/0030-4220(94)90098-1]

11. Matt BH, Lusk RP. Delineation of a deep neck abscess with magnetic resonance imaging. Ann Otol Rhinol Laryngol. 1987 Sep-Oct;96(5):615-7. [Medline: 3314626]

12. Thiruchelvam JK, Songra AK, Ng SY. Intraoperative ultrasound imaging to aid abscess drainage--a technical note. Int J Oral Maxillofac Surg. 2002 Aug;31(4):442-3. [Medline: 12361082] [doi: 10.1054/ijom.2001.0188]

13. Al-Belasy FA. Ultrasound-guided drainage of submasseteric space abscesses. J Oral Maxillofac Surg. 2005 Jan;63(1): 36-41. [Medline: 15635555] [doi: 10.1016/j.joms.2004.05.218]

14. Hall MB, Arteaga DM, Mancuso A. Use of computed tomography in the localization of head-and-neck-space infections. J Oral Maxillofac Surg. 1985 Dec;43(12):978-80. [Medline: 3864955] [doi: 10.1016/0278-2391(85)90016-3]

15. Pogrel MA. The use of ultrasonography in the diagnosis of neck lumps. J Oral Maxillofac Surg. 1982 Dec;40(12):794-6. [Medline: $\underline{\text { 6958840] }}$ [doi: 10.1016/0278-2391(82)90176-8]

\footnotetext{
To cite this article: Infections.

J Oral Maxillofac Res 2011;2(4):e4

URL: http://www.ejomr.org/JOMR/archives/2011/4/e4/v2n4e4ht.pdf

doi: $10.5037 /$ jomr.2011.2404
}

Pandey PK, Umarani M, Kotrashetti S, Baliga S. Evaluation of Ultrasonography as a Diagnostic Tool in Maxillofacial Space 
Copyright (C) Pandey PK, Umarani M, Kotrashetti S, Baliga S. Accepted for publication in the JOURNAL OF ORAL \& MAXILLOFACIAL RESEARCH (http://www.ejomr.org), 29 November 2011.

This is an open-access article, first published in the JOURNAL OF ORAL \& MAXILLOFACIAL RESEARCH, distributed under the terms of the Creative Commons Attribution-Noncommercial-No Derivative Works 3.0 Unported License, which permits unrestricted non-commercial use, distribution, and reproduction in any medium, provided the original work and is properly cited. The copyright, license information and link to the original publication on (http://www.ejomr.org) must be included. 